\title{
Challenges in conducting research on collaborative mental health care: a qualitative study
}

\author{
Nadiya Sunderji MD MPH, Allyson Ion MSc, Annie Zhu BHSc, Athina Perivolaris RN MN, \\ David Rodie MD, Benoit H. Mulsant MD MS
}

Abstract

Background: We sought to understand poor uptake of the Primary Care Assessment and Research of a Telephone Intervention for Neuropsychiatric Conditions with Education and Resources study (PARTNERs), a pragmatic randomized controlled trial of a collaborative care intervention for people experiencing depression, anxiety or at-risk drinking. We explored primary care providers' experience with PARTNERs, and preferences regarding collaborative care models and trials.

Methods: In this qualitative study, we interviewed primary care providers across Ontario who had participated in PARTNERs, using stratified sampling to reach high-, low- and nonreferring providers in urban and rural settings. We audio-recorded, transcribed and thematically analyzed the interviews between May and December 2017, collecting and analyzing data concurrently until achieving saturation.

Results: We interviewed 23 primary care providers. They valued the unique availability of telephone-based coaching for patients but desired greater integration of the coach into their practice. They appreciated expert psychiatric recommendations but rarely changed their practices. Sites varied in organizational adoption and implementation of the study, including whether they designated a local champion, proactively identified eligible patients, integrated the study into existing workflows and reflected on (and revised) practices. These behaviours affected continuing awareness of the study and referral rates.

Interpretation: Study uptake was influenced by the limited relationship between PARTNERs coaches and primary care providers, and variable attention to leadership, training and quality improvement as vital elements of collaborative care. Study designs focusing on implementation could promote reach and penetration of novel interventions in the practice setting and more successfully advance collaborative care implementation.

( ollaborative mental health care involves primary care providers and mental health specialists working together in structured ways to improve access to care, quality of care and outcomes. ${ }^{1,2}$ It is one of the most empirically supported approaches to achieving good outcomes in primary mental health care ${ }^{2-7}$ and is integral to mental health and primary care strategies in Canada. ${ }^{8-12}$ However, well-studied effective models of collaborative care have not been implemented in Canada. ${ }^{13,14}$

The Primary Care Assessment and Research of a Telephone Intervention for Neuropsychiatric Conditions with Education and Resources study (PARTNERs) (Clinicaltrials. gov, no. NCT02345122) was designed to address geographic and human resource barriers that impede the implementation of collaborative care. It was a pragmatic randomized controlled trial assessing the implementation and effectiveness of a collaborative care model delivered by telephone versus enhanced usual care for people experiencing depression, anxiety or at-risk drinking, including mild to moderate alcohol use disorders. ${ }^{15}$ The study intervention included telephone-based symptom monitoring and self-management support provided by a care manager, and recommendations from a psychiatrist to guide pharmacotherapy provided by primary care providers. The study outcomes were reduction in symptom severity and improved quality of life, measured 4, 8 and 12 months after baseline. The study had lower than expected referral rates. ${ }^{16} \mathrm{We}$ conducted a qualitative study with the aim of exploring primary care providers' experiences of PARTNERs, understanding barriers to and facilitators of collaborative care interventions and research, and informing the design of future studies.

Competing interests: Benoit Mulsant reports grants from Brain Canada, the Canadian Institutes of Health Research, the Centre for Addiction and Mental Health Foundation, the Patient-Centered Outcomes Research Institute and the US National Institutes of Health, and nonfinancial support from the US National Institutes of Health, Eli Lilly, Pfizer, Capital Solution Design, HAPPYneuron and General Electric outside the submitted work. No other competing interests were declared.

This article has been peer reviewed.

Correspondence to: Nadiya Sunderji, nsunderji@waypointcentre.ca CMAJ Open 2019. DOI:10.9778/cmajo.20180172 


\section{Methods}

The full qualitative study protocol is provided in Appendix 1 (available at www.cmajopen.ca/content/7/2/E405/suppl/ DC1). We attempted to answer the following questions:

- Perceptions and preferences regarding collaborative care models: How do primary care providers perceive the role for, and the advantages and disadvantages of, the PARTNERs collaborative care intervention, including measurement-based care, care management and psychiatrist decision support?

- Implementation and uptake of the collaborative care model: What aspects of the care model and its implementation in PARTNERs enabled or hindered participation of primary care providers in the provision of collaborative care?

- Referrals to the study: What provider, practice, intervention and study factors influenced the rate of referral to the study? How did primary care providers decide who and when to refer?

- Future research: What features of collaborative care interventions, study design and study processes could increase engagement of primary care providers in future studies?

\section{Theoretical frameworks}

We drew on the Consolidated Framework for Implementation Research ${ }^{17,18}$ to inform sampling, data collection and initial organization of the data. Our data collection was also guided by the theory of planned behaviour. ${ }^{19,20}$

\section{Sampling and recruitment}

Eligible participants for this qualitative study were family physicians, nurse practitioners, directors, nurses and social workers involved in implementing research in 1 of the 14 primary care organizations that participated in PARTNERs as of May 2017. These organizations included 8 Family Health Teams, 3 solo-physician family practices, 2 community health centres and 1 student health clinic. Eight sites were located in the Greater Toronto Area, and 6 were in rural Ontario communities; the latter had populations of less than 165000 and were outside metropolitan commuting zones. The PARTNERs research team knew all eligible participants as referring providers or study liaisons; the qualitative research team did not.

The lead PARTNERs researchers (B.H.M. and A.P.) provided the qualitative study team members (N.S., A.I. and A.Z.) with referral data, from which 2 research team members (N.S. and A.I.) developed a stratified purposive sampling framework whereby we recruited family physicians and nurse practitioners for qualitative interviews based on their individual and clinic referral rates (high, low or nonreferral) and their practice settings (urban v. rural). ${ }^{21,22} \mathrm{We}$ created definitions of high and low referral rates based on the referral data. Practices with high referral rates averaged more than 0.15 referrals per physician or nurse practitioner per month they were involved in PARTNERs. Providers with high referral rates referred more than 0.2 participants per month they were involved in the study, and those with low referral rates referred 0.2 participants or fewer per month. We did not adjust for providers' practice sizes.

We used criterion sampling to recruit the study participants who were directors, nurses or social workers who had contributed to the conduct of research and typically had acted as PARTNERs study liaisons.

A research coordinator contacted eligible participants by fax, telephone and/or email and invited them to participate in a telephone interview about 60 minutes in length. We contacted 10-20 eligible participants at a time across the various recruitment strata and criteria. Owing to lower response rates among providers in the low- and nonreferring strata, we contacted more of these providers. Ultimately, to maximize participation, we contacted most primary care providers and study liaisons (180 of the 190 who were eligible). We conducted qualitative interviews with 23 people across 12 of the 14 PARTNERs sites between May and December 2017. All participants gave informed consent and received a $\$ 200$ honorarium.

\section{Data collection}

Our interviews followed a semistructured interview guide that addressed characteristics of the PARTNERs intervention, outer and inner settings (domains of the Consolidated Framework for Implementation Research), implementation processes, and individual perceptions and beliefs that influence intentions and, in turn, behaviour (see Box 1 for further description of topics and Appendix 2, available at www.cmaj open.ca/content/7/2/E405/suppl/DC1, for the interview guide). ${ }^{17-20}$ One research team member (A.I.) with experience in qualitative research conducted the interviews, which were 46-74 minutes in length, audio-recorded and transcribed.

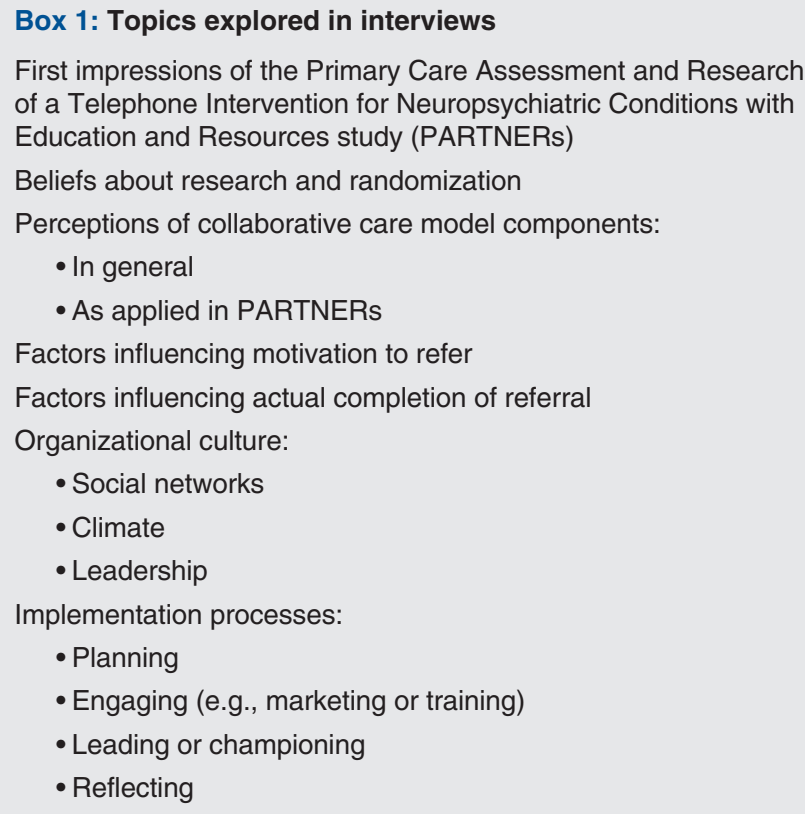




\section{Data analysis}

We conducted a qualitative thematic analysis that drew on grounded theory to develop a mid-level theory to explain primary care providers' referral patterns in PARTNERs. ${ }^{23,24}$ Data collection was concurrent with analysis and continued until theoretical and informational saturation was reached, with no emerging themes. Three research team members (N.S., A.I. and A.Z.) created an initial set of codes based on Consolidated Framework for Implementation Research constructs to categorize the interview data, then independently read several transcripts and generated additional codes. The qualitative research team then met and revised the initial codebook, from which A.Z. coded the remaining transcripts and organized the data using NVivo11 software (QSR International). The analysis team met regularly to discuss broader themes and interrelations emerging from the codes, exploring convergent and divergent themes from the various interviews, looking for patterns, building explanations iteratively and considering rival explanations. ${ }^{23,25} \mathrm{We}$ slightly revised the interview guide to saturate certain codes or test the developing theory by seeking confirming or disconfirming cases..$^{21} \mathrm{We}$ also met with the PARTNERs research team twice to triangulate our preliminary analysis with their experiences and perspectives. We used nonleading interviews, triangulation of multiple data sources and a team approach to data analysis to ensure that diverse perspectives emerged, and we maintained a research audit trail to provide transparency about our choices.

\section{Ethics approval}

The qualitative study was approved by the research ethics boards of St. Michael's Hospital and the Centre for Addiction and Mental Health.

\section{Resullts}

We interviewed 23 participants, who varied greatly in their degree of engagement with PARTNERs (Tables 1 and 2).

\section{Perceptions and preferences regarding collaborative care models}

Participants generally liked the concepts in the collaborative care model and had specific feedback about how these concepts were enacted in PARTNERs (Table 3). They strongly appreciated the provision of care management and identified telephone-based service as helpful and appealing to some patients; however, they had difficulty establishing personal relationships with the off-site care manager and wanted more reciprocal communication. Participants endorsed the idea of health care system redesign toward more team-based care. However, with limited penetration of the intervention in their setting, most primary care providers did not identify the intervention as changing their clinical practices. Finally, participants identified leadership and training as critical to successful implementation of the study and lacking among the core components of the PARTNERs intervention.
Table 1: Characteristics of study participants

\begin{tabular}{|c|c|}
\hline Characteristic & $\begin{array}{c}\text { No. }(\%) \text { of participants } \\
n=23\end{array}$ \\
\hline \multicolumn{2}{|l|}{ Geographic location of practice } \\
\hline Urban & $14(61)$ \\
\hline Rural & $9(39)$ \\
\hline \multicolumn{2}{|l|}{ Health discipline } \\
\hline Family physician & $12(52)$ \\
\hline Nurse practitioner & $5(22)$ \\
\hline Executive director & $3(13)$ \\
\hline Social worker & $2(9)$ \\
\hline Registered nurse & $1(4)$ \\
\hline \multicolumn{2}{|l|}{ Type of practice } \\
\hline Family Health Team & $13(56)$ \\
\hline Community health centre & $6(26)$ \\
\hline Other group practice $†$ & $3(13)$ \\
\hline Solo practice & $1(4)$ \\
\hline Previous participation in research & $18(78)$ \\
\hline \multicolumn{2}{|l|}{ Role in past research $(n=18)$} \\
\hline Referring provider & $8(44)$ \\
\hline Study participant & $4(22)$ \\
\hline Collaborator & $1(6)$ \\
\hline Investigator & $1(6)$ \\
\hline$>1$ role & $4(22)$ \\
\hline \multicolumn{2}{|l|}{ No. of years in practice } \\
\hline Mean \pm SD & $14.0 \pm 12.7$ \\
\hline Median (range) & $9(2-51)$ \\
\hline $\begin{array}{l}\text { Note: SD = standard deviation. } \\
\text { *Except where noted otherwise. } \\
\text { fUniversity student health centre. }\end{array}$ & \\
\hline
\end{tabular}

\section{Study referrals}

Primary care providers stated they were more likely to refer patients with depression or anxiety versus at-risk drinking based on their assumptions about who would and would not benefit from the intervention (Table 4). Referrals were typically visit-triggered and therefore subject to the provider's remembering in the moment; providers were more likely to think of referring for new onset of depression (v. ongoing depression). However, if the patient appeared to be in crisis, randomization became a deterrent; primary care providers prioritized connecting these patients to immediate sources of support (e.g., on-site social worker) and deprioritized discussion of PARTNERs even though these were not mutually exclusive. Providers sometimes referred patients known to be ineligible (e.g., due to an excluded condition) out of a sense of desperation to access mental health services.

Despite the PARTNERs team's continuous outreach efforts, some primary care providers felt they lacked knowledge about the particulars of the study and did not feel 


\begin{tabular}{|c|c|c|c|c|c|}
\hline \multicolumn{6}{|c|}{ Table 2: Study participants by referral stratum } \\
\hline $\begin{array}{l}\text { Geographical } \\
\text { setting }\end{array}$ & $\begin{array}{c}\text { Practice } \\
\text { referral rate* }\end{array}$ & $\begin{array}{l}\text { Individual } \\
\text { primary care } \\
\text { provider } \\
\text { referral rate† }\end{array}$ & $\begin{array}{c}\text { No. of } \\
\text { primary care } \\
\text { providers } \\
\text { eligible } \\
n=175\end{array}$ & $\begin{array}{c}\text { No. of } \\
\text { primary } \\
\text { care } \\
\text { providers } \\
\text { interviewed } \\
n=19\end{array}$ & $\begin{array}{l}\text { No. of site } \\
\text { liaisons } \\
\text { interviewed } \\
\quad n=4\end{array}$ \\
\hline \multirow[t]{6}{*}{ Urban } & $\begin{array}{l}\text { High } \\
(n=4)\end{array}$ & High & 27 & 6 & 1 \\
\hline & & Low & 20 & 1 & 0 \\
\hline & & No referrals & 20 & 1 & 0 \\
\hline & $\begin{array}{l}\text { Low } \\
(n=4)\end{array}$ & High & 3 & 1 & 2 \\
\hline & & Low & 15 & 2 & 0 \\
\hline & & No referrals & 40 & 1 & 1 \\
\hline \multirow[t]{6}{*}{ Rural } & $\begin{array}{l}\text { High } \\
(n=4)\end{array}$ & High & 11 & 0 & 0 \\
\hline & & Low & 4 & 1 & 0 \\
\hline & & No referrals & 7 & 0 & 0 \\
\hline & $\begin{array}{l}\text { Low } \\
(n=2)\end{array}$ & High & 4 & 3 & 0 \\
\hline & & Low & 9 & 0 & 0 \\
\hline & & No referrals & 15 & 3 & 0 \\
\hline \multicolumn{6}{|c|}{$\begin{array}{l}{ }^{*} \text { Practices with high referral rates made more than } 0.15 \text { referrals per month on average per family physician or nurse } \\
\text { practitioner in the practice; practices with low referral rates made } 0.15 \text { or fewer. } \\
\text { tHigh = more than } 0.2 \text { referrals per month on average; low }=0.2 \text { referrals or fewer per month on average. } \\
\text { †There was } 1 \text { site liaison per study site }(n=14) \text { and } 1 \text { liaison for a study site that withdrew from PARTNERs early in the } \\
\text { study; we contacted all of them. }\end{array}$} \\
\hline
\end{tabular}

confident in making referrals. A recommendation from a colleague within their practice influenced their initial intention to refer to PARTNERs, but after making the decision to refer, peer opinions and norms diminished in importance. If providers perceived that a referred patient had greatly benefitted, this reinforced their expectation of positive outcomes for patients and increased their intention to refer.

Primary care providers often presented PARTNERs to their patient as part of a "menu" of options. Some patients preferred other options (e.g., face-to-face therapy) if it was available in the primary care setting and did not perceive an added value or need for the PARTNERs intervention. Some patients experienced language barriers to participation. Beyond that, patients' reasons for declining referral to the study are largely unknown. Notably, some primary care providers whom we thought were nonreferrers or low referrers stated that they had discussed the study with many patients who declined to be referred.

\section{Implementation and uptake of collaborative care model}

Various factors facilitated or inhibited primary care providers' engagement in and referrals to PARTNERs (Appendix 3, available at www.cmajopen.ca/content/7/2/E405/suppl/DC1). Leadership and training, team buy-in, infrastructure and integration into existing workflows were important factors con- tributing to site involvement. Perceived time burden stemming from poor integration into one's usual workflow or cognitive burden of remembering about the study posed barriers for some. Enabling factors included perceiving PARTNERs as a much-needed resource for patients and the community, and ease of the referral process. Practices that referred many patients had developed site-specific practical, time-efficient and proactive strategies to identify and engage eligible patients, for example, contacting patients who were awaiting telepsychiatry consultation, or embedding assessment of patient eligibility and interest into existing interprofessional intake processes.

\section{Interpretation}

In this study, we explored the experiences, perceptions and preferences of primary care providers and study site liaisons who were involved in a pragmatic randomized controlled trial of a collaborative mental health care intervention. Our participants had positive perceptions of collaborative care models; they appreciated the accessibility of telephone-based care management and "indirect" (provider-to-provider) psychiatric consultation, and expressed interest in team-based care. However, their engagement was influenced by organizational characteristics (e.g., how the decision to participate in the study was made, the involvement of champions and 
available alternative resources), implementation activities (e.g., integration of the patient identification and referral process into existing workflows) and, to a lesser extent, beliefs of individual primary care providers (e.g., expected outcomes of the intervention, preferences regarding randomization). Our findings confirm Ontario primary care providers' interest in participating in collaborative care but also identify barriers that may supersede their intentions.

Despite the promise of collaborative care models in improving mental health care in primary care, their successful implementation remains a major gap. Several initiatives have failed to achieve their objectives. Solberg and colleagues ${ }^{26,27}$

Table 3 (part 1 of 2): Perceived strengths and weaknesses of collaborative care in PARTNERs

\begin{tabular}{|c|c|c|c|}
\hline $\begin{array}{l}\text { Collaborative } \\
\text { care element }\end{array}$ & Definition & $\begin{array}{l}\text { How manifested in } \\
\text { PARTNERs (for patients } \\
\text { who received intervention) }\end{array}$ & Participant perspective \\
\hline $\begin{array}{l}\text { Support for } \\
\text { patient self- } \\
\text { management }\end{array}$ & $\begin{array}{l}\text { Coaching, problem solving, } \\
\text { or psychoeducation or } \\
\text { skills-focused } \\
\text { psychotherapy to increase } \\
\text { ability to manage } \\
\text { symptoms and effectively } \\
\text { participate in care and } \\
\text { decision-making }\end{array}$ & $\begin{array}{l}\text { - Lay provider }(\mathrm{MHT}) \\
\text { provided telephone } \\
\text { monitoring and self- } \\
\text { management support } \\
\text { and, later, relapse } \\
\text { prevention support; } \\
\text { telephone calls were } \\
\text { typically weekly } \times 3 \text { mo, } \\
\text { then monthly } \times 3 \text { mo or } \\
\text { potentially longer to a } \\
\text { maximum of } 1 \text { yr } \\
\text { - MHT supervised weekly } \\
\text { by study psychiatrist }\end{array}$ & $\begin{array}{l}\text { - Seen as a unique and valuable resource for patients } \\
\text { (in a broader climate of limited access) } \\
\text { - Strongly expected to be of benefit to many patients } \\
\text { - Telephone communication thought to vary in appeal } \\
\text { and feasibility for patients } \\
\text { - Trusted that MHTs were qualified; some wanted more } \\
\text { familiarity with them } \\
\text { - Would have liked greater integration of MHT into their } \\
\text { setting, more frequent and bidirectional } \\
\text { communication to share their knowledge of the patient } \\
\text { and his or her past treatments, or co-location to } \\
\text { enable "warm handoffs" }\end{array}$ \\
\hline $\begin{array}{l}\text { Use of clinical } \\
\text { information } \\
\text { systems for timely } \\
\text { data }\end{array}$ & $\begin{array}{l}\text { Facilitated flow of patient- } \\
\text { or population-level data to } \\
\text { clinicians, e.g., via reports } \\
\text { of patient results, case } \\
\text { registries, reminder } \\
\text { systems }\end{array}$ & $\begin{array}{l}\text { - Patient's FP or NP } \\
\text { received individual patient } \\
\text { data monthly × } 3 \text { mo } \\
\text { (while MHT followed } \\
\text { patient weekly), then } \\
\text { quarterly (while MHT } \\
\text { followed patient monthly) } \\
\text { for a maximum of } 1 \text { yr } \\
\text { - Reports included Patient } \\
\text { Health Questionnaire- } 9 \\
\text { score and other } \\
\text { questionnaire scores as } \\
\text { appropriate, a brief } \\
\text { summary of care with } \\
\text { MHT and any } \\
\text { recommendations from } \\
\text { study psychiatrist }\end{array}$ & $\begin{array}{l}\text { - Theoretically useful, but some had difficulty recalling } \\
\text { what they received, and blinded patient randomization } \\
\text { also made their opinions difficult to interpret } \\
\text { - Could validate PCP impression, provide information } \\
\text { not known to the PCP, or discuss referrals that were } \\
\text { seen by the PCP as redundant or previously tried } \\
\text { - Telephone contact between MHT and PCP initiated by } \\
\text { MHT was rare and greatly appreciated when it } \\
\text { occurred; very rarely (if ever) initiated by PCP } \\
\text { - Rarely identified any changes to their practice as a } \\
\text { result of receiving reports or knowing about MHT } \\
\text { involvement (perhaps because of practice habits and } \\
\text { small number of their patients involved with } \\
\text { PARTNERs intervention) }\end{array}$ \\
\hline $\begin{array}{l}\text { Delivery system } \\
\text { redesign }\end{array}$ & $\begin{array}{l}\text { Team-based care } \\
\text { (v. physician-only care) to } \\
\text { provide education, } \\
\text { self-management support, } \\
\text { information flow and } \\
\text { overall proactive rather } \\
\text { than reactive care }\end{array}$ & $\begin{array}{l}\text { - Addition of MHT and } \\
\text { study psychiatrist at a } \\
\text { distance }\end{array}$ & $\begin{array}{l}\text { - Embraced the concept of team-based primary care for } \\
\text { people with common mental disorders, } \\
\text { e.g., depression, anxiety; typically identified other } \\
\text { conditions (e.g., bipolar disorder, posttraumatic stress } \\
\text { disorder) as appropriate for follow-up in specialty care } \\
\text { - Many did not view the MHT care manager as an } \\
\text { integrated member of the care team or a resource to } \\
\text { the primary care setting }\end{array}$ \\
\hline $\begin{array}{l}\text { Decision support } \\
\text { for health care } \\
\text { providers }\end{array}$ & $\begin{array}{l}\text { On-site or distal } \\
\text { psychiatrist consultation to } \\
\text { PCPs or provision of } \\
\text { simplified clinical practice } \\
\text { guidelines supported by } \\
\text { clinician champions }\end{array}$ & $\begin{array}{l}\text { Based on discussion with } \\
\text { MHT and an algorithm, } \\
\text { study psychiatrist } \\
\text { provided } \\
\text { recommendations for } \\
\text { optimizing treatment in } \\
\text { reports }\end{array}$ & $\begin{array}{l}\text { - Appreciated study psychiatrist recommendations but } \\
\text { did not necessarily act on them any sooner than the } \\
\text { next scheduled patient appointment }\end{array}$ \\
\hline $\begin{array}{l}\text { Linkage to } \\
\text { community } \\
\text { resources }\end{array}$ & $\begin{array}{l}\text { Referrals to external } \\
\text { resources to support } \\
\text { clinical and nonclinical } \\
\text { needs (e.g., peer support, } \\
\text { exercise, home care) }\end{array}$ & $\begin{array}{l}\text { - Not formally a component } \\
\text { of PARTNERs } \\
\text { intervention }\end{array}$ & $\begin{array}{l}\text { - Mixed perspectives on whether these may be best } \\
\text { identified, introduced and referred to by the local } \\
\text { primary care team versus the distal collaborative care } \\
\text { team }\end{array}$ \\
\hline
\end{tabular}


Table 3 (part 2 of 2): Perceived strengths and weaknesses of collaborative care in PARTNERs

\begin{tabular}{|c|c|c|c|}
\hline $\begin{array}{l}\text { Collaborative } \\
\text { care element }\end{array}$ & Definition & $\begin{array}{c}\text { How manifested in } \\
\text { PARTNERs (for patients } \\
\text { who received intervention) }\end{array}$ & Participant perspective \\
\hline $\begin{array}{l}\text { Support for } \\
\text { health care } \\
\text { organizations }\end{array}$ & $\begin{array}{l}\text { Leadership, training, } \\
\text { staffing, informatics and } \\
\text { other tangible resources to } \\
\text { support adoption and } \\
\text { implementation of } \\
\text { collaborative care goals } \\
\text { and practices }\end{array}$ & $\begin{array}{l}\text { - Not formally a component } \\
\text { of PARTNERs } \\
\text { intervention (although } \\
\text { PARTNERs team did } \\
\text { provide an optional initial } \\
\text { on-site orientation to the } \\
\text { study for local primary } \\
\text { care teams) }\end{array}$ & $\begin{array}{l}\text { - Identified as a major gap } \\
\text { - Leadership support for participation in PARTNERs } \\
\text { varied greatly and influenced adoption and } \\
\text { implementation } \\
\text { - Lack of training and ongoing support resulted in } \\
\text { difficulty (e.g., knowing how to introduce the study to } \\
\text { patients, whether the study was ongoing and } \\
\text { continuing to accept new referrals) } \\
\text { - Interprofessional staff involvement (i.e., beyond } \\
\text { physicians) would be required to facilitate more } \\
\text { proactive care } \\
\text { - Staff turnover was common and created discontinuity } \\
\text { in knowledge of and engagement with the study } \\
\text { - Informatics capabilities (e.g., searches or flags in the } \\
\text { electronic medical record to facilitate identification of } \\
\text { eligible patients) could assist with proactive care; } \\
\text { again, would require interprofessional staff } \\
\text { involvement }\end{array}$ \\
\hline
\end{tabular}

attempted large-scale implementation of collaborative care for depression in the Depression Improvement Across Minnesota - Offering a New Direction (DIAMOND) initiative but experienced variable uptake. As in our study, Whitebird and colleagues $^{28}$ found that leadership support, primary care provider champions and well-integrated care managers influenced DIAMOND's implementation and effectiveness, including key intervention processes such as patient activation, at the clinic level. Finally, the Care of Mental, Physical and Substance-Use Syndromes (COMPASS) initiative implemented collaborative care for patients with depression and poorly controlled diabetes or cardiovascular disease in 172 clinics across 8 US states and found large variations between clinic outcomes. ${ }^{29}$ The authors concluded that these differences were related to many contextual factors that were "unmeasured and unmeasurable." Our findings and those of the DIAMOND initiative ${ }^{26,27}$ suggest that these contextual differences are actually measurable. We argue for greater attention toward the following factors when implementing and evaluating future studies: leadership, change management, primary care provider champions, integration of care managers, integration into existing workflows and training for all team members.

More broadly, engagement of primary care physicians is crucial to quality-improvement initiatives aiming to improve health care system integration. ${ }^{30}$ Successful transformation of the health care system considers the adopter's perspective and gains his or her investment through meaningful engagement early in the change process and true partnership in decisionmaking and codesign. ${ }^{31,32}$

Our findings also resonate with prior research suggesting common challenges in conducting research trials in primary care. Time constraints and assimilation into workflows are widely viewed as hindering research uptake. ${ }^{33-38}$ Explaining research studies to patients and completing referral processes take time in an already busy clinic schedule, and resources to support these actions are often perceived as inadequate. ${ }^{30,35,37}$ In PARTNERs, the referral was easy to complete, but the cognitive burden of remembering to offer PARTNERs during clinic visits and the perceived difficulties in engaging patients in mental health care hampered participation in the study. In some cases, primary care providers' doubts about the clinical relevance of particular research studies can pose a barrier; however, our study participants viewed PARTNERs as highly relevant. ${ }^{34,39-43}$ Here again, active involvement of champions and peers would facilitate participation by explaining the relevance of the research (making it seem worthwhile) and setting up efficient workflows for recruitment. ${ }^{44-46}$ These issues might have been anticipated had primary care providers initially been involved in the study design (e.g., as part of the study team).

\section{Limitations}

Our definitions of high and low referral rates were not derived from the literature. We did not collect information on participants' gender. The low referrers and nonreferrers we interviewed had limited knowledge of the PARTNERs intervention (variously attributed to such factors as missed meetings, unread emails and staff turnover), such that their recommendations were based on their practice experience and their conceptual understanding of collaborative care but were not grounded in direct experience with PARTNERs; this may have affected the quality of their interviews. Participants' 
Table 4 (part 1 of 2): Primary care providers' perspectives on patient and study characteristics that influenced referrals

\begin{tabular}{|c|c|c|}
\hline Variable & Increased likelihood of referral & Decreased likelihood of referral \\
\hline \multicolumn{3}{|l|}{$\begin{array}{l}\text { Patient } \\
\text { characteristics }\end{array}$} \\
\hline $\begin{array}{l}\text { Mental health } \\
\text { diagnosis congruent } \\
\text { with telephone- } \\
\text { based support }\end{array}$ & $\begin{array}{l}\text { Anxiety disorders: "I think, for anxiety ... it was really } \\
\text { helpful as well, actually, by phone call initially because a } \\
\text { lot of my patients did have struggles getting to any } \\
\text { appointment because they're too anxious to leave the } \\
\text { house, they're too anxious to do just anything. ... They'll } \\
\text { answer the call, and they actually like talking with } \\
\text { somebody from the safety of their own home." (1002, } \\
\text { family physician) }\end{array}$ & $\begin{array}{l}\text { Comorbid substance use and alcohol use: "I think addiction care over } \\
\text { the phone might be kind of hard, personally. And I didn't refer any of my } \\
\text { clients in particular related to ... alcohol use ... because I've never had a } \\
\text { patient who was ... willing to cut down drinking or was interested in } \\
\text { getting support for cutting down drinking who would be willing to do it by } \\
\text { phone." (15001, nurse practitioner) }\end{array}$ \\
\hline $\begin{array}{l}\text { Stage of mental } \\
\text { illness }\end{array}$ & $\begin{array}{l}\text { New onset of depression/anxiety: "I certainly have a lot } \\
\text { of patients with depression and anxiety who I didn't } \\
\text { refer, [for referrals] it tends to be people who are walking } \\
\text { in with a new symptom. ... I think for people l've been } \\
\text { following for a long time, it's just not in my algorithm." } \\
\text { (1004, family physician) }\end{array}$ & $\begin{array}{l}\text { Acute/crisis: "It was mostly if we felt that a client was a little bit more } \\
\text { acute and not so much in a more stable environment for that phase in } \\
\text { regards to their depression or anxiety. Then we would focus more on } \\
\text { getting that client's needs met in regards to the counselling that [he or } \\
\text { she] needed or being seen by a psychiatrist. So not so much being } \\
\text { followed and screened but more intervention. ... Once we felt that, they } \\
\text { were a little bit more stable.... And a lot of them did actually go through } \\
\text { the PARTNERs study afterwards." (15003, nurse practitioner) }\end{array}$ \\
\hline $\begin{array}{l}\text { Sociodemographic } \\
\text { characteristics }\end{array}$ & $\begin{array}{l}\text { Patient characteristics influencing motivation and } \\
\text { perceived capacity to self-manage: "I have kind of } \\
\text { more of the working, younger, healthier, a better } \\
\text { mixed population ... which probably also is why I had } \\
\text { more referrals than others - because my patients } \\
\text { are more motivated to be self-managed and seek } \\
\text { access to a dietitian, access to a social worker, that } \\
\text { kind of stuff. And I have an easier time getting my } \\
\text { patients to do that than they do at the other sites } \\
\text { [that have] ... a sicker, older population." (15002, } \\
\text { nurse practitioner) }\end{array}$ & $\begin{array}{l}\text { Language barriers: "Language barrier was one that we took into } \\
\text { consideration as well. ... We do have a really high francophone } \\
\text { community. So that was one of the barriers that we encountered quite a } \\
\text { bit.... We have a big elderly population as well. ... They do deal with } \\
\text { depression, especially during the wintertime as well. So it would have } \\
\text { been a great resource for them because it doesn't require them to come } \\
\text { out of their home ... it reduces the risks of falls and all that. But I wasn't } \\
\text { able to utilize the PARTNERs study for them because they only speak or } \\
\text { understand French." (15003, nurse practitioner) }\end{array}$ \\
\hline $\begin{array}{l}\text { Primary care } \\
\text { provider perceptions } \\
\text { of patient } \\
\text { preferences }\end{array}$ & $\begin{array}{l}\text { Timely response to a patient need: "Typically what } \\
\text { would happen is a patient would come in in crisis, in } \\
\text { need. Although we do have a social worker, they needed } \\
\text { something more. ... And so offering them this as an } \\
\text { interim, knowing that they would still get to the } \\
\text { psychiatrist, seemed to alleviate some of that anxiety } \\
\text { about 'Okay, when am I going to have that appointment } \\
\text { and how come I can't get in tomorrow?' And so having } \\
\text { that sort of stepping stone, sometimes it worked } \\
\text { extremely well, and I know that some patients thought it } \\
\text { was great." (12001, manager/director) }\end{array}$ & $\begin{array}{l}\text { Patient preferences for embedded/local service: "At our family health } \\
\text { team, we have a social worker who does counselling. So when I bring } \\
\text { these things up, I sort of put the option for counselling that we have on } \\
\text { the table. And most of my other currently depressed people are a little } \\
\text { more in that } 40-, 50 \text {-year-old range, and they were quite happy to just do } \\
\text { regular counselling. So it wasn't that I intentionally didn't refer, it was that } \\
\text { they were happy with the resources at the site." (5001, family physician) } \\
\text { "I have some patients who just have had a bad experience with 'the } \\
\text { hospital,' and they won't have anything to do with it. So l've had that a } \\
\text { couple of times." (1004, family physician) } \\
\text { Relationship with primary care provider: "I wouldn't refer people who are } \\
\text { really busy or involved in a lot ... or I felt like we need to work on the } \\
\text { therapeutic alliance a little bit more." (1001, social worker) }\end{array}$ \\
\hline \multicolumn{3}{|l|}{$\begin{array}{l}\text { Study } \\
\text { characteristics }\end{array}$} \\
\hline Eligibility criteria & $\begin{array}{l}\text { Hope to link patient with support through study: "There } \\
\text { were a couple of people I referred who had trauma who } \\
\text { I still hoped ... would get in, and they were not eligible. } \\
\text { So I still referred some people even though they met } \\
\text { your exclusion criteria just in hopes that they might get } \\
\text { some extra support." (15001, nurse practitioner) }\end{array}$ & $\begin{array}{l}\text { High prevalence of comorbid disorders in practice: "A huge portion of } \\
\text { my practice [is] high rates of substance abuse, high rates of } \\
\text { posttraumatic stress disorder and high rates of bipolar [disorder]. So to } \\
\text { come across somebody with just depression or anxiety is pretty rare." } \\
(15002, \text { nurse practitioner) }\end{array}$ \\
\hline
\end{tabular}

descriptions of their experience with PARTNERs may have also been affected by the time elapsed since referring or having patients actively engaged in the study, and by not knowing whether their patient(s) had been allocated to the intervention or control arm of the trial. Participants may have been biased by the honorarium in their decision to participate or in the perspectives they expressed. Patients were not interviewed for this qualitative study. Feedback from patients who completed the PARTNERs study (described elsewhere ${ }^{15}$ ) was positive but does not help us understand the perspectives of those who chose not to participate.

\section{Conclusion}

Future studies should test approaches to enhance collaborative care delivery at a distance and to build relationships between the central and distal sites. Leadership and training are key but often overlooked components of the chronic care model that should be emphasized in future studies. Finally, implementation research in collaborative care is critically needed to understand how to modify day-to-day practice and sustain these changes over time. Using implementation science and study designs conducive to practicelevel implementation (e.g., cluster randomization or stepped-wedge trials) is essential to ensure adoption and 


\begin{tabular}{|c|c|}
\hline Variable & Increased likelihood of referral \\
\hline Randomization & $\begin{array}{l}\text { Randomization necessary to evaluate intervention: "I } \\
\text { think it's [randomization] part of the research beast. ... If } \\
\text { you want a good study, you probably have to do some } \\
\text { sort of randomization. And so I understand that from a } \\
\text { research principle. So it doesn't particularly affect me } \\
\text { negatively." (5001, family physician) } \\
\text { Hope to link patient with support through study: "No, I } \\
\text { never considered whether they would get the help or } \\
\text { not. I just knew that this is something we could offer } \\
\text { them. ... And I hope that those people that needed the } \\
\text { help got it ... it [randomization] didn't stop me from doing } \\
\text { it." (12001, manager/director) }\end{array}$ \\
\hline
\end{tabular}

Expected benefits for patients

\section{Expected benefits} for providers
Intervention accessibility: "Access to counselling here is a problem. And so just hoping to increase services is helpful. Lots of patients here have difficulty with access in terms of driving, being able to actually go somewhere to see a counsellor. So the fact that ... it's phone contact was helpful. Not every person is super comfortable talking to somebody in person. And so phone sometimes helps sort of initiate or get things moving." (12002, nurse practitioner)

Witnessing patient benefits: "Until we actually made our first referral, understood the ramifications for the patients and actually saw some feedback, it didn't really connect with us." (12001, manager/director)

\section{Study as a resource augmenting usual care ( $v$. study} as "research"): "It's a research study about these 2 different interventions. It's not a psychiatrist necessarily taking over my patient, saying 'Here, we're going to see this patient and assess [her] fully, and then we'll do all this diagnosis and may start medications, and then we'll send [her] back to you, and then work together.' ... It's actually more of me looking after the patient but with these additional options ... an add-on to my usual care. It's not replacing it. ... I just want [the patient] to be randomized, and it doesn't matter because I'm going to be doing the usual care anyways. This is an add-on that could help [the patient]." (11001, family physician)

"I don't have the time in my schedule to actually make ... just a monitoring phone call appointment every week. Maybe on a monthly basis or so, then, yeah, that's more feasible. But the PARTNERs study actually allowed me to give a little bit ... step back a bit, and I knew that [the patient was] being monitored. And if there was a real concern, then it would be brought to my attention. So it was opening up my schedule." (15003, nurse practitioner)
Lack of knowledge about intervention: "I don't think I knew enough about [PARTNERs] or was comfortable enough about it during that time." (13001, nurse practitioner)

"I'm assuming it's a knowledge gap, a deficit in education as to exactly how either the mental health technicians or nurses can help the patient. Sometimes I think there's a stigma attached to an intervention that has the [term] 'research study' attached to it." (13002, manager/director) Redundancy of service: "It was introduced as something that could be helpful. But I guess maybe it just didn't take off ... [owing] to all the factors - of some of the social workers seeing it as maybe threatening their service ... patients seeing it as a duplication." (18001, social worker) "Maybe l'm referring to our local psychiatric referral resource.... So you may not see it [referrals to PARTNERs] because ... it's hard to work with 'the hospital' when I have a local resource." (11001, family physician)

Note: PARTNERs $=$ Primary Care Assessment and Research of a Telephone Intervention for Neuropsychiatric Conditions with Education and Resources study. 
sustainability, and to generate new and useful knowledge about the real-world effectiveness of collaborative care.

\section{References}

1. Kates N, Mazowita G, Lemire F, et al. The evolution of collaborative mental health care in Canada: a shared vision for the future. Can 7 Psychiatry 2011;56: $1-10$.

2. Vanderlip ER, Rundell J, Avery M, et al. Dissemination of integrated care within adult primary care settings: the collaborative care model. Washington: American Psychiatric Association and Academy of Psychosomatic Medicine; 2016. Available: www.psychiatry.org/psychiatrists/practice/professional-interests/ integrated-care/collaborative-care-model (accessed 2016 Sept. 14).

3. Archer J, Bower P, Gilbody S, et al. Collaborative care for depression and anxiety problems. Cochrane Database Syst Rev 2012;10:CD006525.

4. Butler M, Kane RL, McAlpine D, et al. Integ ration of mental bealth/substance abuse and primary care. Evidence report no 173. Rockville (MD): Agency for Healthcare Research and Quality; 2008. Available: www.ahrq.gov/downloads/ pub/evidence/pdf/mhsapc/mhsapc.pdf (accessed 2012 Feb. 26).

5. Gilbody S, Bower P, Fletcher J, et al. Collaborative care for depression: a cumulative meta-analysis and review of longer-term outcomes. Arch Intern Med 2006;166:2314-21.

6. Woltmann E, Grogan-Kaylor A, Perron B, et al. Comparative effectiveness of collaborative chronic care models for mental health conditions across primary, specialty, and behavioral health care settings: systematic review and metaanalysis. Am 7 Psychiatry 2012;169:790-804.

7. Integrating mental bealth into primary care: a global perspective. Geneva: World Health Organization, and Singapore: World Organization of Family Doctors; 2008. Available: www.who.int/mental_health/policy/services/ mentalhealthintoprimarycare/en/ (accessed 2013 Nov. 13).

8. Open minds, healthy minds: Ontario's comprehensive mental health and addictions strategy. Toronto: Ontario Ministry of Health and Long-Term Care; 2011. Available: www.health.gov.on.ca/en/common/ministry/publications/reports/ mental_health2011/mentalhealth_rep2011.pdf (accessed 2014 Apr. 14).

9. The action plan for mental bealth in New Brunswick 2011-18. Fredericton: Province of New Brunswick. Available: www.gnb.ca/0055/pdf/2011/7379\%20english.pdf (accessed 2016 Nov. 16).

10. Creating connections: Alberta's addiction and mental heath action plan: 2011-2016. Government of Alberta; 2011. Available: www.albertaaddictionserviceproviders. org/ccactionplan2011.pdf (accessed 2016 Nov. 16).

11. Healthy minds, healthy people: a 10-year plan to address mental bealth and substance use in British Columbia. Victoria: BC Ministry of Health Services and Ministry of Children and Family Development; 2010. Available: www.health.gov.bc.ca/ library/publications/year/2010/healthy_minds_healthy_people.pdf (accessed 2016 Nov. 16)

12. A vision for Canada: family practice - the patient's medical home [position paper]. Mississauga (ON): College of Family Physicians of Canada; 2011. Available: www.cfpc.ca/uploadedFiles/Resources/Resource_Items/PMH_A_ Vision_for_Canada.pdf (accessed 2013 Nov. 10).

13. Sunderji $\bar{N}$, Ghavam-Rassoul A, Ion A, et al. Driving improvements in the implementation of collaborative mental bealth care: a quality framework to guide measurement, improvement and research. Toronto: St. Michael's Hospital; 2016. Available: www.researchgate.net/publication/312539646_Driving_ Improvements_in_the_Implementation_of_Collaborative_Mental_Health_ Care_A_Quality_Framework_to_Guide_Measurement_Improvement_and_Research (accessed 2017 Jan. 11).

14. Mulvale G, Danner U, Pasic D. Advancing community-based collaborative mental health care through interdisciplinary family health teams in Ontario. Can 7 Commun Ment Health 2008;27:55-73.

15. Zaheer S, Garofalo V, Rodie D, et al.; PARTNERs Study Group. Computeraided telephone support for primary care patients with common mental health conditions: randomized controlled trial. 7MIR Ment Health 2018;5:e10224.

16. Navaratnam N, Fitzgibbon K, Garofalo V, et al. CAMH Integrated Care Research Project: a telephone-based intervention for mental health problems in primary care patients [poster]. Canadian Psychiatric Association annual conference; 2016 Sept. 22-24; Toronto.

17. Consolidated Framework for Implementation Research (main page). Available: http://cfirguide.org/ (accessed 2017 Jan. 30).

18. Damschroder LJ, Aron DC, Keith RE, et al. Fostering implementation of health services research findings into practice: a consolidated framework for advancing implementation science. Implement Sci 2009;4:50.

19. Ajzen I. Behavioral interventions based on the theory of planned behavior. Amherst (MA): University of Massachusetts Amherst; 2006. Available: https:// people.umass.edu/aizen/pdf/tpb.intervention.pdf (accessed 2017 Jan. 29).

20. Ajzen I. The theory of planned behavior. Organ Behav Hum Decis Process 1991; 50:179-211.

21. Palinkas LA, Horwitz SM, Green CA, et al. Purposeful sampling for qualitative data collection and analysis in mixed method implementation research. Adm Policy Ment Health 2015;42:533-44.

22. Onwuegbuzie AJ, Collins KMT. A typology of mixed methods sampling designs in social science research. Qual Rep 2007;12:281-316.
23. Strauss AL, Corbin JM. Basics of qualitative research: grounded theory procedures and techniques. Newbury Park (CA): Sage Publications; 1990.

24. Strauss AL, Corbin JM, editors. Grounded theory in practice. Thousand Oaks (CA): Sage Publications; 1997.

25. Glaser BG, Strauss AL. The discovery of grounded theory: strategies for qualitative research. Piscataway (NJ): Transaction Publishers; 1999.

26. Solberg LI, Crain AL, Maciosek MV, et al. A stepped-wedge evaluation of an initiative to spread the collaborative care model for depression in primary care. Ann Fam Med 2015;13:412-20.

27. Solberg LI, Crain AL, Jaeckels N, et al. The DIAMOND initiative: implementing collaborative care for depression in 75 primary care clinics. Implement Sci $2013 ; 8: 135$.

28. Whitebird RR, Solberg LI, Jaeckels NA, et al. Effective implementation of collaborative care for depression: What is needed? Am 7 Manag Care 2014;20: 699-707.

29. Rossom RC, Solberg LI, Magnan S, et al. Impact of a national collaborative care initiative for patients with depression and diabetes or cardiovascular disease. Gen Hosp Psychiatry 2017;44:77-85.

30. Goodyear-Smith F, York D, Petousis-Harris H, et al. Recruitment of practices in primary care research: the long and the short of it. Fam Pract 2009;26: 128-36.

31. Dickinson H, Ham C. Engaging doctors in leadership: review of the literature. Birmingham (UK): University of Birmingham; 2008. Available: www. birmingham.ac.uk/Documents/college-social-sciences/social-policy/HSMC/ research/leadership-literature-review.pdf (accessed 2019 Jan. 31).

32. Engagement: the grey literature - What's known about engagement in the NHS, and what do we still need to find out? Birmingham (UK): Aston Business School, Aston University; 2011. Available: https://assets.publishing.service.gov.uk/ government/uploads/system/uploads/attachment_data/file/215456/dh_129659. pdf (accessed 2019 Jan. 31).

33. Bevan H. Being ready for change. London (UK): Guy's and St Thomas' Foundation Trust; 2018. Available: www.slideshare.net/helenbevan/being-ready -for-change (accessed 2019 Jan. 31).

34. McKinstry B, Hammersley V, Daly F, et al. Recruitment and retention in a multicentre randomised controlled trial in Bell's palsy: a case study. BMC Med Res Methodol 2007;7:15.

35. Page MJ, French SD, McKenzie JE, et al. Recruitment difficulties in a primary care cluster randomised trial: investigating factors contributing to general practitioners' recruitment of patients. BMC Med Res Methodol 2011;11:35.

36. van der Windt DA, Koes BW, van Aarst M, et al. Practical aspects of conducting a pragmatic randomised trial in primary care: patient recruitment and outcome assessment. Br 7 Gen Pract 2000;50:371-4.

37. Rosemann T, Szecsenyi J. General practitioners' attitudes towards research in primary care: qualitative results of a cross sectional study. BMC Fam Pract 2004;5:31.

38. Salmon P, Peters S, Rogers A, et al. Peering through the barriers in GPs' explanations for declining to participate in research: the role of professional autonomy and the economy of time. Fam Pract 2007;24:269-75.

39. Ngune I, Jiwa M, Dadich A, et al. Effective recruitment strategies in primary care research: a systematic review. Qual Prim Care 2012;20:115-23.

40. Foy R, Parry J, Duggan A, et al. How evidence based are recruitment strategies to randomized controlled trials in primary care? Experience from seven studies. Fam Pract 2003;20:83-92.

41. Johnston S, Liddy C, Hogg W, et al. Barriers and facilitators to recruitment of physicians and practices for primary care health services research at one centre. BMC Med Res Methodol 2010;10:109.

42. Kenealy TW, Hao'uli S, Arroll B. A qualitative study of recruiting for investigations in primary care: plan, pay, minimise intermediaries and keep it simple. SAGE Open Med 2015;3:2050312115596649.

43. Peto V, Coulter A, Bond A. Factors affecting general practitioners' recruitment of patients into a prospective study. Fam Pract 1993;10:207-11.

44. Asch S, Connor SE, Hamilton EG, et al. Problems in recruiting communitybased physicians for health services research. 7 Gen Intern Med 2000;15:591-9.

45. Graffy J, Grant J, Boase S, et al. UK research staff perspectives on improving recruitment and retention to primary care research; nominal group exercise. Fam Pract 2009;26:48-55.

46. Leathem CS, Cupples ME, Byrne MC, et al. Identifying strategies to maximise recruitment and retention of practices and patients in a multicentre randomised controlled trial of an intervention to optimise secondary prevention for coronary heart disease in primary care. BMC Med Res Methodol 2009;9:40.

Affiliations: Waypoint Centre for Mental Health Care (Sunderji), Penetanguishene, Ont.; Li Ka Shing Knowledge Institute (Sunderji), St. Michael's Hospital; Department of Psychiatry (Sunderji, Rodie, Mulsant), University of Toronto, Toronto, Ont.; Waypoint Research Institute (Sunderji), Penetanguishene, Ont.; St. Michael's Hospital Mental Health Research Group (Ion), Toronto, Ont.; School of Social Work (Ion), McMaster University, Hamilton, Ont.; Faculty of Medicine (Zhu), University of Toronto; Medical Psychiatry Alliance \& Collaborative Care (Perivolaris), Telepsychiatry (Rodie) and Campbell Family Mental Health Research Institute (Mulsant), Centre for Addiction and Mental Health, Toronto, Ont. 
Contributors: Nadiya Sunderji, Allyson Ion, Benoit Mulsant and Athina Perivolaris conceived and designed the study. Nadiya Sunderji, Allyson Ion and Annie Zhu acquired and analyzed the data. Nadiya Sunderji, Allyson Ion and Annie Zhu drafted the manuscript, and Benoit Mulsant, Athina Perivolaris and David Rodie revised it critically for important intellectual content. All of the authors contributed to interpreting the data, approved the version to be published and agreed to be accountable for all aspects of the work.

Funding: This research was funded by Bell Canada and the Centre for Addiction and Mental Health Foundation.
Acknowledgement: The authors thank Laura Carvalhal Schoffel for assistance with recruitment for qualitative interviews.

Disclaimer: The opinions, results and conclusions reported in this article are those of the authors and are independent from the funding source. The funders had no role in the design and conduct of the study, collection, management, analysis and interpretation of the data, and preparation, review or approval of the manuscript.

Supplemental information: For reviewer comments and the original submission of this manuscript, please see www.cmajopen.ca/content $/ 7 / 2$ / E405/suppl/DC1. 